\title{
METÓDA VÝVINOVEJ DIAGNOSTIKY: SKRÍNING PSYCHOMOTORICKÉHO VÝVINU S-PMV Informácie o projekte ${ }^{1}$
}

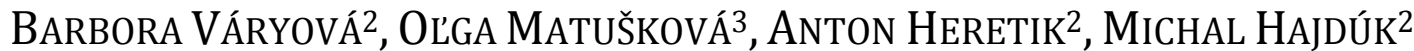

\begin{abstract}
Abstrakt: Prinášame informáciu o tvorbe novej metódy vývinovej diagnostiky (S-PMV) určenej pre pediatrov, ale aj odborníkov, ktorí pracujú v oblasti včasnej diagnostiky detí do 3 rokov. Ide o pôvodnú slovenskú metódu, ktorá vzniká na základe potreby aktualizovat' a štandardizovat' postupy vyšetrení na odhal'ovanie rizika oneskoreného vývinu a vývinových porúch. Metóda pozostáva zo súboru dotazníkov určených na vyplnenie rodičmi, ktorých položky prešli viacstupňovým výberom a boli konfrontované s anamnézou a s posúdením diet'at'a pediatrom. S-PMV bol overovaný na vzorke 2710 detí, ktorú sme získali v spolupráci so 45 pediatrami v rámci celého Slovenska.
\end{abstract}

Klíčová slova: vývinový skríning, včasná diagnostika, vývinové oneskorenie, rizikové deti

Vývinové skríningy sú určené na zachytenie detí z populácie, ktoré sú rizikové z hl'adiska ich d'alšieho vývinu. Vo väčšej miere sa vo svete využívajú od konca 60. rokov minulého storočia. Na Slovensku nemáme na tieto účely žiadny moderný skríningový nástroj, pediatrom sú odporúčané metódy zo 70. rokov, bez aktualizovaných noriem (napr. Vývinový skríning vydaný v r. 1979, Vlachove tabul'ky z roku 1972). Posudzovanie vývinovej úrovne je preto založené najmä na pozorovaní diet’at'a, rozhovore s rodičom a klinických dojmoch odborníka.

Snahy o zefektívnenie metód včasnej vývinovej diagnostiky a zdokonalenie systému zachytávania rizikových detí, sú stredobodom záujmu odborníkov všade na svete (American Academy of Pediatrics, 2006; Earls, Hay, 2006; Dunkle, 2005; Sandler et al., 2001 a i.). V súčasnosti sú kladené vyššie požiadavky na vývinové skríningy najmä v zmysle efektivity metód a ich prediktívnej sily. Aj ked' sa na prvý pohl'ad môže zdat', že konkrétny obsah položiek vo vývinových testoch sa až tak nemení, mení sa forma a interpretácia pri posudzovaní výsledkov v určitých súvislostiach. Je to dané aj tým, že

\footnotetext{
1 Text vznikl na základě příspěvku prezentovaného na konferenci Psychologická diagnostika: Výzkum, prevence a poradenství, konané v Brně 19.-21. 6. 2013 (http://psychodiagnostika.fss.muni.cz/2013).

2 Katedra psychológie, Filozofická fakulta UK, Gondova 2, 81499 Bratislava

${ }^{3}$ Detská fakultná nemocnica s poliklinikou Bratislava, Limbová 1, 83340 Bratislava
} 
znalost' vývinovej psychopatológie upozorňuje na viaceré rizikové faktory, ale dokáže aj presnejšie opísat' prvé signály (prekurzory) niektorých vývinových porúch v ranom veku (napr. poruchy autistického spektra, narušená komunikačná schopnost' a pod.). Práve prediktívna validita je preto diskutovanou témou.

Viaceré štúdie (napr. Meisels, 1989) upozorňujú tiež na potrebu revalidizácie starších metód, aby boli spol'ahlivo zodpovedané otázky ohl'adom ich senzitivity a špecifity. Dochádza k revíziám, ale aj tvorbe nových metód. Kvalita skríningových nástrojov na tieto účely je tesne prepojená s úpravou celého systému od diagnostiky po poskytovanie vývinových intervencií a poradenstva.

Náš príspevok poskytuje niekol'ko aktuálnych informácií o projekte "Skríning"4 (skríning psychomotorického vývinu, d’alej S-PMV), ktorého hlavným ciel’om je zefektívnit' vyšetrenia psychomotorického vývinu detí raného veku na Slovensku. Ide o dlhodobý projekt (s podporou MZ SR), ktorý prebieha od roku 2008. Iniciovaný bol Detskou fakultnou nemocnicou s poliklinikou a jeho ciele boli viacej krát prezentované na odborných fórach (Váryová, Matušková, 2013). Projekt reaguje na konkrétnu potrebu vytvorenia vývinovej metódy pre pediatrickú prax, ktorú pocit’ujú mnohí pediatri (ako ukázal prieskum Matuškovej O., Kormanovej A. a Vicianovej K., 2007) a tiež na potrebu vytvorit' štandardné postupy pri povinných preventívnych prehliadkach, kde sa sleduje aj psychomotorický vývin detí. V budúcnosti sa počíta s prepojením systému zdravotnej starostlivosti a prístupu k vývinovým intervenciám a poradenstvu pre deti s identifikovaným rizikom.

\section{Tvorba metódy S-PMV a jej charakteristika}

S-PMV je vo forme dotazníka (v budúcnosti sa počíta aj s elektronickou formou), ktorý vypĺňa rodič (osoba, ktorá diet’a vel'mi dobre pozná). Ked’že S-PMV je určený ako nástroj pre pediatrov, je nutné zo strany pediatra skontrolovat' a posúdit', či výsledky sú v zhode s klinickým dojmom a dopytovat' sa na sporné položky. Súčast'ou skríningu budú presné usmernenia pre pediatra, ako administrovat' S-PMV, vyhodnocovací systém a podklady $\mathrm{k}$ interpretácii.

Pri zostavovaní dotazníka sme postupovali na základe dôkladnej analýzy položiek z viacerých štandardizovaných vývinových metód, predovšetkým zo skríningových metód (tab. 1).

\footnotetext{
${ }^{4}$ Projekt na riešenie úlohy Národného programu starostlivosti o deti a dorast v SR na roky 2008 - 2015: Pilotáž skríningov psychomotorického vývinu pre 2.-11. preventívnu prehliadku, tiež podporovaný MZ SR. Primárnym ciel'om projektu je doplnit' pre primárnu starostlivost' absentujúci, legislatívou požadovaný štandardizovaný nástroj s normami pre vyšetrenia psychomotorického vývinu detí pri preventívnych prehliadkach, vykazovanými ako zdravotné výkony pod kódom 950 a 953 . Na projekte spolupracujú odborníci z praxe DFNsP (PaedDr. O. Matušková) a z Katedry psychológie FiF UK v Bratislave (Mgr. B. Váryová, PhD., Doc. Mgr. A. Heretik, PhD., Mgr. M. Hajdúk).
} 
Tab. 1: Zoznam použitých metód vývinovej diagnostiky k výberu položiek

\begin{tabular}{|c|c|c|}
\hline Metóda & $\begin{array}{c}\text { Spôsob } \\
\text { posudzovania }\end{array}$ & Norma \\
\hline $\begin{array}{l}\text { Neuropsychologisches Entwicklung } \\
\text { Screening (NES) }\end{array}$ & 0 & $\begin{array}{c}\text { závisí od veku, oblasti } \\
\text { a počtu splnených položiek }\end{array}$ \\
\hline $\begin{array}{l}\text { Bayley Scales of Infant and Toddler } \\
\text { Development/Screening test (Bayley-III@) }\end{array}$ & Škála, O, R & dá sa vypočítat' pre daný vek \\
\hline $\begin{array}{l}\text { Parent Evaluation of Developmental Status - } \\
\text { Developmental Milestones (PEDS-DM) }\end{array}$ & $\mathrm{R}$ & $84 \%$ \\
\hline $\begin{array}{l}\text { Parent Evaluation of Developmental Status } \\
\text { (PEDS) }\end{array}$ & $\mathrm{R}$ & - \\
\hline Ages and Stages Questionnaire (ASQ-3) & $\mathrm{R}$ & $85,8 \%$ \\
\hline Child Developmental Review (CDR) & $\mathrm{R}, \mathrm{O}$ & 750 \\
\hline Child Developmental Chart (CDC) & $\mathrm{R}, \mathrm{O}$ & $15 \%$ \\
\hline $\begin{array}{l}\text { Mníchovská funkčná vývinová diagnostika } \\
\text { (MFVD) }\end{array}$ & škála & $95 \%$ \\
\hline Gesell test & škála & $50 \%$ \\
\hline Brunet - Lézine test & škála & $50 \%$ \\
\hline Taylorovej skúška stavby z kociek & - & - \\
\hline $\begin{array}{l}\text { Modified Checklist for Autism in Toddlers } \\
\text { (MCHAT) }\end{array}$ & $\begin{array}{l}\text { skríning - } \\
\text { autizmus }\end{array}$ & - \\
\hline
\end{tabular}

Pozn.: Spôsob posudzovania položiek v jednotlivých metódach: 0 - odborník, R - informácie od rodičov

Širší výber položiek sme konzultovali s expertami a následne overovali ich špecifickost' k veku. Pri výbere položiek bol uplatnený normatívny prístup, t.j. typické správanie detí bolo priradené k priemernému veku detí, v ktorom sa toto správanie prejavuje a tiež zohl'adnenie psychopatológie porúch vývinu založené na sledovaní tzv. prekurzorov. Položky zastupujúce jednotlivé vývinové domény sa odlišovali „normou“, ktorá bola nastavená nad 75 \%, čo je v súlade s údajmi Bayleyovej (2006), ktorá oneskorenie, resp. narušenie vývinu charakterizovala „ako najmenej 25\% oneskorenie v prejavoch $v$ porovnaní s rovesníkmi“. Popri orientačnom kritériu 75\% zastúpenia (t.j. miera splnenia jednotlivých položiek určených pre dané vekové obdobie by mala byt' najmenej $75 \%$ ), bolo druhým kritériom splnenie vekovej špecifickosti (t.j., aby sa nevyskytlo významné, takmer $100 \%$ splnenie vekovo špecifickej položky v inom období. Ciel'om bolo zistit', nakol'ko jednotlivé položky skríningu S-PMV tieto kritériá splńajú.

Formulácia položiek bola upravená tak, aby boli zrozumitel'né pre posudzovatel'ov, čo bolo tiež predmetom overovania. Vyplnenie skríningu si nevyžaduje špeciálne pomôcky (hračky, knihy), je založené na poznaní a bežnom pozorovaní diet’at’a rodičom. Našou 
snahou je, aby položky neboli zložité a aby ich dokázal posúdit' aj rodič bez vzdelania. Dotazník by mal byt' pútavo koncipovaný, s jednoduchou a časovo nenáročnou administráciou, aby sa predišlo stereotypnému zaškrtávaniu odpovedí, ked’že pre väčšinu rodičov detí s typickým vývinom sa môžu položky zdat’ príliš jednoduché.

S-PMV sa skladá zo súboru 5 dotazníkov, ktoré zachytávajú obdobie medzi 4. týždňom až 36. mesiacom chronologického veku diet'at'a. Rozdelené sú tak, aby vek zodpovedal jednotlivým povinným preventívnym prehliadkam u pediatra (2.-11. preventívna prehliadka PP). Vyplnenie každého dotazníka trvá približne 5 až 10 minút.

Pre deti po prvom roku života sme vytvorili dve dlhé verzie dotazníka S-PMV. Ich vyplnenie trvá cca 20-30 minút. Pre obdobie 12 až 18 mesiacov (kryje sa s 9.-10. PP) a pre obdobie 24 až 36 mesiacov (kryje sa s 11. PP) je k dispozícii rozsiahlejší súbor položiek, ktorý podrobnejšie mapuje jednotlivé vývinové domény (hrubá motorika, jemná motorika, adaptívne správanie, reč, sociálne správanie), ako aj vybrané prejavy v správaní a charakteristiky detí. Ciel'om je zachytit’ niektoré špecificky odlišné znaky v zmysle možných prekurzorov (napr. imitácia činností, symbolická hra, spoločná pozornost' a i.). S-PMV určený pre deti vo veku medzi druhým a tretím rokom (11. PP) vznikal od v roku 2009. Neskôr bol v pilotáži (na vzorke detí N 491) overovaný výber položiek, štruktúra, aj navrhovaný spôsob vyhodnotenia (Čuboňová, 2011) a neskôr bol doplnený orientačnými normami. O S-PMV a získaných výsledkoch sme podrobne referovali na odborných fórach (Váryová, Matušková, 2013, Váryová, Čuboňová, 2012).

\section{Aktuálny stav: overovanie skríningov S-PMV}

Hlavnou úlohou etapy projektu, v ktorej sa nachádzame, bolo získat’ východiskové údaje k validizácii a štandardizácii novej metódy S-PMV.

Zber normatívnych údajov prebiehal od decembra 2012 do konca apríla 2013. Nadviazali sme spoluprácu so 45 primárnymi pediatrami z celej SR. Vzorku tvorilo 2710 detí (1384 chlapcov, 1319 dievčat) vo veku od narodenia do 42 mesiacov. Získané údaje sú $\mathrm{v}$ súčasnosti podrobené štatistickej analýze a niektoré kroky podl'a potreby konzultujeme s d’alšími odborníkmi z príslušnej oblasti. Finálna verzia skríningu bude pripravená k decembru 2013 a overenie obsahu i formy bude prebiehat' v praxi v roku 2014. Pre bližšiu predstavu početnosti výskumnej vzorky uvádzame hodnoty v Tab. 2.

Tab.2: Normatívna vzorka - počty detí a ich percentuálne zastúpenie podl’a veku

\begin{tabular}{|l|c|c|c|c|c|c|c|c|}
\hline $\begin{array}{l}\text { Vek detí } \\
\text { v mesiacoch }\end{array}$ & $\mathbf{0 - 6}$ & $\mathbf{6 - 1 2}$ & $\mathbf{1 2 - 1 8}$ & $\mathbf{1 8 - 2 4}$ & $\mathbf{2 4 - 3 0}$ & $\mathbf{3 0 - 3 6}$ & $\mathbf{3 6 - 4 2}$ & $\mathbf{4 2 +}$ \\
\hline N 2710 & 963 & 757 & 427 & 52 & 171 & 242 & 80 & 4 \\
\hline$\%$ & 35.7 & 28.1 & 15.8 & 1.9 & 6.3 & 9 & 3 & 0.1 \\
\hline
\end{tabular}


Zbieranie normatívnych údajov prebehlo prostredníctvom dotazníkov S-PMV (papierová verzia), ktoré dal pediater na vyplnenie rodičom počas preventívnych prehliadok. Posúdenie vyplneného dotazníka, údaje $\mathrm{z}$ anamnézy a posúdenie stavu vývinu diet'ata doplnili pediatri. Mená detí boli kódované z dôvodu zachovania anonymity.

Z výsledkov spracovania prvých údajov hodnotenia vývinového stavu detí pediatrom (N 2710): pediatri uviedli „typický vývin“ (vývinové prejavy v norme) u 94,49 \% detí a „oneskorenie vývinových prejavov za vývinovou normou" u 5,21\%. Tieto údaje sú podobné, ako uvádzaná prevalencia v rôznych materiáloch a štúdiách vo svete. Hodnoty sú rôzne, často je prevalencia uvádzaná pre „vývinové poruchy“ (nie pre vývinové oneskorenie) a pohybuje sa medzi $2-3 \%$ vo veku 0 až 2 roky a $8-10 \%$ pre vek 2 až 5 rokov (napr. PEDS: DM, Glascoe, Robertshaw a kol., 2008). „Významné oneskorenie, vývinovú poruchu“ zachytili slovenskí pediatri u 0,30 \%.

Nesúhlas pediatra s hodnotením rodiča bol zaznamenaný len v 1,3\% prípadov. Tieto dotazníky boli vylúčené z d’alšej analýzy v rámci procese tvorby noriem.

V súvislosti so získavaním údajov pre účely noriem boli dôležité informácie od pediatrov $\mathrm{v}$ súvislosti s rizikami uvádzanými $\mathrm{v}$ anamnéze a rodinným prostredím detí. Tieto údaje budú podrobne analyzované kvôli prediktívnej validite metódy, pričom sa počíta aj s longitudinálnym sledovaním detí v rámci d’alšej etapy projektu. Sledovanie a zaznamenávanie rizikových faktorov môže rovnako pomôct' včasnému odhaleniu oneskoreného vývinu, ked’že u detí s prítomnost'ou rizikových faktorov je zvýšená pravdepodobnost' výskytu vývinových porúch (American Academy of Pediatrics, 2006; Hamilton, 2006).

V Tab. 3 uvádzame niektoré z demografických údajov, ktoré sme zist’ovali a ktoré budú predmetom podrobnej analýzy $\mathrm{v}$ súvislosti $\mathrm{s}$ vývinovými ukazovatel'mi, $\mathrm{s}$ vierohodnost'ou získaných informácií prostredníctvom rodičov, ale aj v súvislosti $\mathrm{s}$ celkovou zrozumitel'nost'ou položiek v dotazníkoch. 
Tab. 3: Vybrané demografické charakteristiky rodičov detí z normatívnej vzorky (počet, percentá)

\begin{tabular}{llcc}
\hline \multirow{2}{*}{ Sociálne dávky } & Nie & 2339 & $86.4 \%$ \\
& Áno & 369 & $13.6 \%$ \\
\hline \multirow{2}{*}{ Rizikové prostredie } & Nie & 2553 & $94.3 \%$ \\
& Áno & 153 & $5.7 \%$ \\
\hline \multirow{2}{*}{ Vzdelanie matky } & Základné & 270 & $10.0 \%$ \\
& Stredoškol. bez maturity & 373 & $13.8 \%$ \\
& Stredoškol. s maturitou & 1166 & $43.1 \%$ \\
& Vysokoškolské & 894 & $33.1 \%$ \\
\hline \multirow{2}{*}{ Vzdelanie otca } & Základné & 260 & $9.8 \%$ \\
& Stredoškol. bez maturity & 519 & $19.4 \%$ \\
& Stredoškol. s maturitou & 1136 & $42.7 \%$ \\
& Vysokoškolské & 748 & $28.1 \%$ \\
\hline Bydlisko & Krajské mesto & 337 & $12.7 \%$ \\
& Mesto & 1019 & $38.2 \%$ \\
& (od 2 000 obyvatelov) & & $49.1 \%$ \\
\hline & Dedina & & \\
\hline
\end{tabular}

\section{Záver}

Vytvorenie kvalitného skríningu, ktorý by spíňal prísne kritériá, sa stalo pre nás z viacerých dôvodov vel'kou výzvou. Hlavným zámerom nášho príspevku bolo informovat' o aktuálnom stave riešenia projektu „Skríning“. Pretavenie vybraných položiek do finálnej verzie skríningu tak, aby vznikol praktický „užívatel’sky priatel'ský“ skríningový nástroj, bude d'alšou úlohou dlhodobého projektu.

Plánovaná finálna verzia novej metódy skríningu psychomotorického vývinu (S-PMV) pre deti od narodenia do troch rokov bude ukončená koncom roku 2013 a jej overovanie v praxi (obsahu i formy) bude prebiehat' v roku 2014. 0 výsledkoch budeme odbornú verejnost' informovat'. 


\section{Literatúra:}

American Academy of Pediatrics. 2006. Identifying infants and young children with developmental disorders in the medical home : an algorithm for developmental surveillance and screening. In Pediatrics [online]. ISSN 1098-4275. 2006; 118(1):405-20 [cit. 2009-0123]. Dostupné na: http://pediatrics.aappublications.org/cgi/reprint/118/1/405.pdf

Bayley, N. 2006. Bayley Scales of Infant and Toddler Development : Administration manual. Third edition. San Antonio : The Psychological Corporation. 2006. 266 pp.

Dunkle, M. 2005. High Quality Developmental Screening [online]. May 31, 2005 [cit. 2009-0401]. Dostupné na: http://www.dbpeds.org/articles/detail.cfm?TextID=\%20373

Čuboňová, L. 2011. Diagnostika prekurzorov rizikového vývinu v pediatrickej praxi: Tvorba experimentálnej verzie skríningu psychomotorického vývinu (S-PMV). Diplomová práca. Filozofická fakulta UK. Katedra psychológie.

Earls, M.F., Hay, S.S. 2006. Setting the Stage for Success: Implementation of developmental and Behavioral Screening and Surveillance in Primary Care Practice: The North Carolina Assuring Better Child Health and Development (ABCD) Project. In Pediatrics [online]. ISSN 1098-4275. July 2006. Volume 118. Number 1. pp. e183-e188 [cit. 2009-04-01]. Dostupné na: http://pediatrics.aappublications.org/cgi/reprint/118/1/e183.pdf

Glascoe, F.P., Robertshaw, N.S. 2008. PEDS: Developmental milestones A tool for Surveillance and Screening: Professional's Manual. Nolensville: Ellsworth \& Vandermeer Press, 2008.

Hamilton, S. 2006. Screening for developmental delay: Reliable, easy-to-use tools : Win win solutions for children at risk and busy practitioners. In The Journal of family practise [online]. ISSN 1365-2214. 2006 [cit. 2011-02-02]. Dostupné na: $<$ http://www.jfponline.com/Pages.asp?AID=4101\&UID=>

Matušková, O., Kormanová, A., Vicianová, K. 2007. Otázky skríningu psychomotorického vývinu v rámci preventívnych pediatrických prehliadok u detí do 3 rokov, In: Pediatria. 2007. ISSN 1336-863X

Meisels, S.J. 1989. Can developmental Screening Tests Identify Children Who are Developmentaly at Risk? Pediatrics. Vol.83. No4. Apr. 1989. pp. 578-585. Special Articles. Copyright 2001. American Academy of Pediatrics.

Sandler, A. D., et al. 2001. Developmental Surveillance and Screening of Infants and Young Children : Commitee on Children With Disabilities. In Pediatrics [online]. ISSN 1098-4275. July 2001. Vol. 108. No. 1. pp. 192-195 [cit. 2009-04-01]. Dostupné na: $<$ http://pediatrics.aappublications.org/cgi/content/full/108/1/192?maxtoshow=\&HITS=1 $0 \&$ hits $=10 \&$ RESULTFORMAT $=\&$ fulltext=developmental+surveillance + and + screening + of + in fants+and+young+children\&searchid=1\&FIRSTINDEX=0\&sortspec=relevance\&resourcetyp $\mathrm{e}=\mathrm{HWCIT}>$

Váryová, B., Čuboňová, L’. 2012. Skríning psychomotorického vývinu - analýza a interpretácia obáv rodičov ohl'adom vývinu svojho diet’at’a. In: Universitas Comeniana. Psychologica XLI. Univerzita Komenského v Bratislave. STIMUL FiF UK. 2012. ISBN: 978-808127-057-4.

Váryová, B., Matušková, O. 2013. Skríning psychomotorického vývinu S-PMV - metóda určená pre pediatrickú prax. In: Prostor v nás a mezi námi - respekt, vzájemnost, sdílení. Sborník z konference XXX. Psychologické dni 2012. 12.-14. zářrí 2012, Olomouc. Ed.: D. Heller, J. Kotrlová, I. Sobotková. ISBN 978-80-244-3492-6. 


\section{Váryová, B., Matušková, 0., Heretik, A., \& Hajdúk, M. (2015):}

The method of developmental diagnostics: Screening of psychomotor development S-PMV. Information about the project.

The contribution provides information about creating a new method of developmental diagnostics (S-PMV) designed for pediatricians, as well as professionals working in the field of early diagnostics of children under 3 years. This is the original Slovak method which arises from the need to update and standardize procedures for examinations to detect the risk of delayed development and developmental disorders. The method consists of a set of questionnaires designed to be filled by parents, whose items have gone through a multi-stage selection and were confronted with a history and with assessment of a child by pediatrician. S-PMV was tested on a sample of 2,710 children, which we acquired in cooperation with 45 pediatricians within Slovakia.

Keywords: developmental screening, early diagnostics, developmental delay, children at risk 